\title{
Flexibility and security in the labour market: An analysis of the governance of inequality
}

\author{
Colin Crouch
}

Published online: 18 May 2010

(C) Institut für Arbeitsmarkt- und Berufsforschung 2010

\begin{abstract}
The financial crisis drew attention to the way in which workers in certain countries had been able to sustain consumption through housing and consumer credit despite insecure labour-market positions. This indicates a need to expand the analysis of the relationship between flexibility and security in labour markets beyond the normal scope of labour and social policy to include many other aspects of not only public policy but also corporate practice that affect that relationship.

Individuals are seen as based within a number of collectivities within which life chances are collectively determined (or CLCs). These collectivities are subject to various forms of governance. Finally, attention is given to the dimension of sustainability, the capacity of any combinations of policies and practices to endure self-destructive tendencies. The governance mechanisms of CLCs are then seen as using one or more strategies for achieving a certain balance between uncertainty and security: externalization of risk on to other CLCs; postponement of risk-bearing to future periods of time; externalization of risk on to certain members of the CLC itself; widespread sharing within the CLC.

This approach is then used to consider the main policies and practices relevant to the field: employment law; social policies directly delivering services; advancement of skill and employability levels available within the population; public promotion and/or protection of sectors and production locations perceived to be of strategic importance, including public employment; government demand management; insurance and pensions; trading relationships
\end{abstract}

C. Crouch (区)

Warwick Business School, The University of Warwick,

CV4 7AL Coventry, UK

e-mail: c.crouch@warwick.ac.uk among nation states with different export and import patterns; consumer credit to sustain mass consumption; locally clustered economic sectors; the shadow economy; managerial organization of activities offering varying degrees of security among different countries and regions, including supply chain management; internal labour markets and organization of work and work roles; collective bargaining; inter-generational transfers and support; the protection of property-owning elites from labour-market uncertainty.

\section{Flexibilität und Sicherheit auf dem Arbeitsmarkt: eine Analyse der Governance der Ungleichheit}

Zusammenfassung Die Wirtschaftskrise hat darauf aufmerksam gemacht, wie die Arbeiter in bestimmten Ländern es geschafft hatten, den Konsum durch Immobilien- und Konsumentenkredite trotz unsicherer Arbeitsmarktpositionen aufrechtzuerhalten. Dies zeigt die Notwendigkeit, die Analyse des Verhältnisses von Flexibilität und Sicherheit in Arbeitsmärkten über den normalen Umfang von Arbeitsund Sozialpolitik hinaus zu erweitern, um viele weitere Aspekte - nicht nur der öffentlichen Ordnung sondern auch der Geschäftspraktiken -, die dieses Verhältnis beeinflussen, mit einzubeziehen.

Individuen werden als in einer Anzahl von Kollektiven lebend dargestellt, in welchen ihre Chancen im Leben kollektiv bestimmt werden („Collectivities of Life Chances“ [CLCs]). Diese Kollektive unterliegen verschiedenen Formen der Governance. Letztlich wird die Dimension der Nachhaltigkeit, also die Fähigkeit einer beliebigen Kombination von Politiken und Praktiken, trotz ihrer selbstzerstörerischen Tendenzen zu überleben, untersucht. Die Governance-Mechanismen von CLCs werden dann dargestellt, als nutzten sie eine oder mehrere Strategien, 
um ein gewisses Gleichgewicht zwischen Unsicherheit und Sicherheit zu erlangen: Risiken auf andere CLCs zu externalisieren; das Eingehen von Risiko auf einen späteren Zeitpunkt zu verschieben; Risiken auf bestimmte Mitglieder des eigenen Kollektivs zu verteilen und das weitverbreitete Verteilen von Risiken innerhalb des CLC.

Dieser Ansatz wird dann benutzt, um die für das Gebiet relevanten Hauptpolitiken und -praktiken zu untersuchen: das Arbeitsrecht; Sozialpolitiken, die Leistungen direkt erbringen; das Vorankommen von in der Bevölkerung vorhandenen Kompetenzen und der Beschäftigungsfähigkeit; die öffentliche Vermarktung bzw. der Schutz von Sektoren und Produktionsstandorten, die als von strategischem Wert gelten einschließlich des öffentlichen Dienstes; Nachfragemanagement durch die Regierung; Versicherung und Rente; Handelsbeziehungen zwischen Nationalstaaten, die unterschiedliche Export- und Importmuster aufweisen; Konsumentenkredit, um den Massenkonsum aufrecht zu erhalten; örtlich gebündelte Wirtschaftssektoren; der Schwarzmarkt; die betriebswirtschaftliche Organisation von Aktivitäten die unterschiedliche Sicherheitsgrade zwischen verschiedenen Ländern und Regionen bieten, einschließlich des Supply-Chain-Managements; interne Arbeitsmärkte und die Organisation von Arbeit und Arbeitsrollen; Tarifverhandlungen; intergenerativer Wissenstransfer und intergenerative Unterstützung; das Absichern von vermögensbesitzenden Eliten gegen arbeitsmarktbedingte Unsicherheiten.

\section{Introduction}

For several years now there has been a general consensus among international and national policy-makers and experts that labour markets will work more efficiently the more they approximate to perfect, frictionless markets. In perfect markets rational actors perfectly anticipate all shocks, or at least turn uncertainties into tradable risks, against which they insure. It follows from this that all attempts by public policy or other collective action to provide security against uncertainty by intervening in market processes have to be broken down, as they impede this self-correcting capacity of the market (see OECD 1994 for the locus classicus of this approach in international policy-making).

The key word in the policy-making that has resulted from this has been "flexibility". Labour flexibility has many meanings, and industrial sociology recognizes forms of flexible working within work organizations and not just as movements in the external labour market (Wilthagen and Tros 2004). Eurostat (2007, Chap. 3) currently recognize three distinct forms: internal qualitative, or functional, which concerns a wide range of ways in which workers may take on varied and complex tasks; internal numerical, concerning the deployment of flexible working time and manning arrangements among an existing workforce; and external, concerning movement of workers among firms. Wilthagen and Tros (2004) insist that it should not be reduced to the three of these alone. However, in the dominant stream of policy thinking flexibility has until recently been a euphemism for ease of hire and fire, and for a general elimination of constraints that might be placed on management's freedom to dispose of labour as it wants. Very many policy measures taken by governments around the world have been moves in this direction. There is however a problem. The perfect labour market may well be an impossible dream. It is not possible for economic models to incorporate all shocks. It cannot be assumed that actors in the labour market have adequate knowledge rationally to anticipate likely uncertainties and to be able to turn them into tradable risks. If that is the case, then measures to provide for various kinds of security against economic uncertainty may be necessary if the confidence of labour-market participants is to be sustained; and the market itself requires their confidence, as labour-market participants are also consumers. But, of course, measures of this kind then impede the progress towards the perfect labour market.

This dilemma has been recognized by policy-makers, in two different ways. First, in democracies they have found it politically impossible to remove social policy supports for economic security in the way recommended by the economic theory. Secondly, and more constructively, there is important evidence that some forms of security provision do not seem to impede labour-market efficiency but even seem to be positively associated with it. This has now been recognized in the OECD's 2006 follow-up to its 1994 Jobs Study (OECD 2006a).

If this was already the case, the search for the perfect labour market has been even more thoroughly thrown off course by the financial crisis of 2007-2008. This has been a crisis at the heart of the neo-liberal model of market governance. Financial markets of the Anglo-American type, the type responsible for the crisis, had been seen as the purest expression of what could be achieved by the pure market, with their capacity for perfect anticipation and future discounting through calculated risk sharing (Fama 1971, 1991). Less widely understood, these markets have also been directly relevant to the problem of the labour market: instead of depending on social security benefits and job protection, workers could offset their labour-market uncertainty by taking on unsecured loans, the risky character of which was "lost" by being extensively traded in secondary markets. The consumer spending unleashed by these loans stimulated demand in the economy, further reducing uncertainty. It achieved similar goals to Keynesian demand management, but using market means alone and 
without recourse to government intervention (Crouch 2009; Bellofiore and Halevy 2009).

We now know that this model was not sustainable. First, it is questionable whether the Anglo-American financial model really meets the criteria of the pure market. It seems to depend on traders not knowing the dimensions of the risks concealed within the bundles of assets in which they trade; but the perfect market depends heavily on rational actors motivated to acquire perfect knowledge. Second, the rush by governments to sustain the banking system after its collapse made that system dependent on political intervention of a kind completely incompatible with the rules of the market. The model seems to be surviving; the interests vested in it are too powerful for it to be permitted to collapse. But it can no longer be seen as a pure market, or as a market solution to problems of economic uncertainty. It is a distorted market, and one that has become dependent on government regulation and massive financial support. Whether or not the moral hazard introduced by governments intervening in this way will lead to worse outcomes than if governments had allowed the markets to engage in their own major correction is as yet unknown.

In this context existing doubts surrounding the search for pure labour markets are doubly reinforced. First, if the financial system can exist only with support external to itself, including state support, should the labour market be expected to be any different? Second, if, in some countries, insecure or flexible labour markets were only feasible because workers had access to sources of credit not dependent on their labour incomes, what happens after the collapse of the subprime mortgage and other unsecured credit markets? If that system was the market's answer to labour-market insecurity, was it more cost-effective and efficient than orthodox social policy?

In this context it is necessary to revisit the whole question of labour-market uncertainty and the most appropriate measures for reconciling workers' demands for protection from it with the need for flexibility. The crisis in unsecured credit enables us to see that not only formal public labour market and social policy are relevant to attempts at reducing economic security; and we should not assume that unsecured credit has been the only other relevant set of practices. Several other areas of social life, such as the family, have also been important, in at least some societies; areas that have not been involved in the central ideological conflict between markets and public social policy.

In particular, we need to consider "practices" alongside policies. Practices contrast with policies in being implicit, with consequences that may be unrecognized by those following them, and in the control of many groups going beyond the scope of public policy. For example, the different implications for men and women of the way in which a transnational corporation organizes its supply chains may be more important for differences between the genders than any government policies on equal opportunities in the various countries involved. Or, to take another example, the availability of unsecured mortgages may be more important to low-paid workers' perceptions of their economic (if not their employment) security than any labour laws.

The aim of this paper is to provide a framework for examining the relationship between flexibility and security that takes account of this wider context. Particular attention will also be paid to the implications of different flexibility and security regimes for the issues of inequality and sustainability. It is proposed that studies of the balance between flexibility and security, which currently concentrate on just a few familiar strands of formal labour and social policy, need to expand to consider the full context within which these measures play their part.

\section{Historical background}

The task of rethinking must begin with an attempt to gain some historical perspective. The social settlements around the place of labour in society that were established around the end of the Second World War in most of western Europe (somewhat earlier in Scandinavia) included the establishment or consolidation of both welfare states and industrial relations regimes that recognized certain rights of organized labour to participate in settling terms and conditions of work. The two policy fields then went their separate ways. For much of the second half of the 20th century the main concern of public policy over industrial relations in western economies was containment of the inflationary tendencies of Keynesian demand management. This presented a number of classic collective action problems, which provided the main analytical frame for academic study (Crouch 1993, Chap. 2; Olson 1982). Wider social policy - once seen as closely linked to labour policy within the general concept of Sozialpolitik - sometimes played a subsidiary role, providing material for deals and bargains, but was mainly seen as a different subject, to be studied with different if related analytical tools. While there was always a diversity of employment statuses, in general that of the full-time, indefinite, dependent employee was becoming increasingly dominant as self-employment and various forms of job tenure associated with agriculture declined. Policy-making in all these fields was largely contained at the level of the nation state; and there was little concern for sustainability issues. Certainly, economic growth was seen as entirely beneficial, and questions were not asked about the environmental impacts of the kinds of activity that produced such growth.

Industrial relations and social policy came together again in a limited way during the inflationary crises of the 1970s. 
Both wage bargaining in a context of politically guaranteed full employment and governments' alleged tendencies to finance improving social welfare provision through money creation rather than taxation were regarded as major factors in that inflation. During the 1980s and 1990s - the timing varies in different countries - this all changed. Governments' turn to monetary as opposed to demand management policies in response created new environments in both policy areas.

In the new context the business of industrial relations has shifted to being a series of deals and conflicts over how, and by whom, the burdens of economic uncertainty should be distributed, and through what forms of employment contracts and their terms and conditions. In this process a number of different institutions engage in new practices; and there is a new diversity of employment forms and tenures. Further, social policy becomes increasingly integrated with employment and industrial relations practices, being central to the distribution and redistribution of uncertainty. This happens partly through the rise of active labour-market policy, and also through the re-appearance of social policy issues in industrial conflict; in some countries, particularly France, major strikes have tended to be concerned with pensions rather than pay. In most of Europe, these changes have taken place during and under pressure from a period when economic growth can no longer be taken for granted. This then raises the priority of growth as a policy objective, but at precisely the moment when environmental concerns have also made it a priority to consider qualitative as well as quantitative characteristics of growth.

Countries in central and eastern Europe had a different experience during the western Keynesian period, but the state socialist regimes also, in their way, protected working populations from economic uncertainty. Today these countries share a similar policy agenda to their western counterparts, but usually with far higher levels of uncertainty and with very different institutional contexts. In addition, the state socialist growth model had made use of many industrial processes that were environmentally highly damaging, and these countries now face the need to adapt to new environmental standards while wanting to maximize growth in order to raise income levels.

The emergence of uncertainty as an organizing theme

Uncertainty emerged as a central organizing theme for research through the dialectic over flexibility and security emerging from international, and particularly European, policy debates over the past two decades, with the European Commission's White Paper Growth, Competitiveness and Employment (1993), the OECD's Jobs Study (1994), and later the Commission's Lisbon report (European Commission 2005) standing as crucial documents. Globalization and associated sectoral changes in employment, as well as rising costs of social policy, challenged former approaches to reconciling work and welfare based on guaranteeing security to the working population, as well as to those outside the labour force on grounds of age, disability, motherhood or inability to find work. As noted above, the ideal of the frictionless labour market, in which uncertainty would be resolved and shocks countered through rational actors' rational adaptation of expectations, provided the guiding ideal for policy-makers. If public policy had a role, it was in facilitating the inception of this ideal, through policies: to maximize labour force participation in order to reduce dependency rates and increase the tax base; to improve the capacity of individuals to prepare themselves for participation in the labour market; and to increase work flexibility among those within the existing workforce and those outside it (Davies and Freedland 2007). There was a perceived need to create a labour force that is skilled, trained and adaptable within labour markets responsive to economic change. These were all variants of neo-liberalism, mixed with strong ingredients of pro-active government social policy that did not fit the neo-liberal framework at all. More "pure" neo-liberal policy-makers pointed instead to the importance of individuals' making provision from their own resources to convert the uncertainties they face into financial risk products, through private pension and insurance provision, and other purchases of financial assets. Whether or not it was explicit policy, in some countries there also emerged the practice that people should use their residential property as a means of leveraging increased financial resources. It certainly was public policy in several countries to encourage people on modest incomes to enter financial markets and to enjoy increases in residential property values.

Only rarely therefore have policy-makers, including senior managements of large corporations, been able to tear down the security protections perceived by the theory as reducing labour-market efficiency. Rather, they have had to provide assurance to most members of the working population that, barring natural disasters and the unforeseen, they should be able to plan their lives with reasonable confidence. This requires consideration of the different forms of labour flexibility, which can have very different implications for security. There has been particular interest in policies and practices that claim to combine flexibility and security, leading policy-makers to developed such hybrids as the primarily Danish and Dutch concept of "flexicurity", but the overall range of policies and practices involved in the reformulation of the balance between flexibility and security is considerably more extensive than this. Some of these are captured in the Commission's 2006 Green Book (European Commission 2006), which brings together work flexibility, pensions and vocational training as components of an extensive flexi- 
curity package. But this extension still falls far short of embracing all elements of public policy and corporate practice that contribute to particular balances between security and flexibility.

For EU member states further challenges are created by requirements to achieve these labour-market policy goals while at the same time combining economic competitiveness with both environmental and social cohesion and sustainability, as set out in the Sustainable Development Strategy (Gothenberg Report [European Commission 2001]) and with special reference to the energy sector in the 2007 Energy Policy for Europe (European Commission 2007). Now they also need to deal with the changed financial landscape.

\section{Uncertainty, security, sustainability and governance}

As stated at the outset, it is necessary to revisit the entire terms of this debate. Before entering substantive discussion, it is necessary to define some key terms more clearly, in particular security, sustainability and governance.

\subsection{Uncertainty and security}

The management of security presents itself primarily as the governance of economic uncertainty. "Uncertainty" can be distinguished from "risk". Following Knight's (1921) original formulation, as developed by Beck (1986), Luhmann (1991) and others, we treat risk as referring to calculable uncertainties. Uncertainty therefore includes both risks and incalculable uncertainties. The distinction is important for the mechanisms that are used to govern uncertainty. Being calculable, risks can be traded. There are therefore markets in risk, and the estimation, trading and management of risk in this sense have become major activities of the financial sector of many economies. The market is therefore an important form of uncertainty governance, as will be discussed further below.

Uncertainty can never be resolved by creating certainty, as it is not possible to provide this quality in economic life. Actors can take steps to manage uncertainty through the market, as in risk management; or they can seek a degree of protection from it, through various measures lying outside the market. It is helpful if we reserve the concept of "security" to refer generally to these non-market measures, both those normally associated with ideas of social security and labour-market regulation, and those that emerge through corporate practice, the actions of trade unions or the work of families. The provision of various forms of security does not necessarily imply an environment in which no risks are taken. Actors are free to choose to take risks; an environ- ment of economic security protects them from risks that are not of their own choosing.

Analysts have also enabled us to break down the general block of "security" into a number of components, which may be combined in very different ways to produce the final balance in any one work situation. For example, Wilthagen (2002) and Wilthagen and Tros (2004) distinguish among: job security, relating to tenure in a particular job; employment security, relating to the reliability of being continuously in work, but not necessarily in the same post; income security, reliability of a continuing income stream, irrespective of whether one is in work or not; and "combination" security, the ability to achieve a work-life balance. Standing (1999) also considers: employability security, relating primarily to access to vocational education and training; workplace security, health and safety; and representational security, or the right to trade union recognition.

Entrepreneurial risk-taking behaviour may in fact be discouraged by an environment of high uncertainty, as the calculations on which risk-taking are based are distorted by large amounts of exogenous unpredictability. This is one of the reasons why there is a general interest in reducing economic uncertainty. Another is the desire that can be imputed to the majority of people who do not wish to be entrepreneurs to have economic circumstances that are as predictable as possible, in the sense of being free from shocks. Finally, the producers and sellers of goods and services have an interest in a general environment where there is not constant anxiety among the populations in the markets in which their customers are located.

Individuals are unable to provide unaided an environment for their own security, as the provision of an environment requires collective action of some kind. Very rich and powerful individuals are able to solve this problem by ordering the collective action of others to provide such environments for them, using either political or economic means. The great majority of persons, however, depend on their membership of one or more collectivities for this provision. The term "community of fate" was introduced into modern sociology by Stinchcombe (1965) to describe such collectivities. He defined this term to mean an organization in which the success of individual participants is closely linked with the success of the larger collectivity. Writing for a handbook on organizations, he was particularly concerned with that form of human institution, but the term can also be applied more generally to include looser forms of association. Indeed, it is most often used today to refer to nations. The term "community" is confusing here, as below this word will be used in its stricter, normal sociological meaning, referring to primary, tight, face-to-face and largely informal groupings. The term "fate" might also seem to imply powerlessness in the face of a fixed destiny. What Stinchcombe wanted to identify by his term were a whole range of collectivities within 
which life chances are collectively determined. This prosaic term hardly trips off the tongue like "community of fate", but it is more accurate for our purposes. We shall therefore use it instead of "community of fate", but retaining Stinchcombe's meaning, and referring to it by the abbreviated acronym CLC.

The relevant institutions that for present purposes can then form CLCs are: international regimes, nation states, other local territorial levels of government and membership associations, employing organizations, families. A study of economic security needs to look at what is being done by each of these, at their relative importance for individuals' lives, and at relationships and conflicts among them.

\subsection{Sustainability}

In addition to the challenges that CLCs confront from exogenous shocks, they also face problems of sustainability produced by their own activities. Many forms of continued high economic growth, supportive in many ways of reducing uncertainty, produce damage to the natural environment that eventually damages both economic and physical security. Further, arrangements for protection against disruption from economic change may prevent innovation and therefore negatively affect the economic success on which security itself depends. On the other hand, change from which individuals are unprotected can threaten their confidence as consumers and therefore itself become unsustainable. Flexibility as such is not necessarily desirable in itself; it is important to the extent that institutions that do not possess this quality become unsustainable, whether by becoming uncompetitive, by damaging the environment, or for some other reason.

The search is therefore on for policies of sustainable security, for arrangements that pre-empt and offset any potential threats that policies and practices pose to their own sustainability. We shall define a sustainable institution or practice as one which is capable of reproducing itself without developing self-destructive tendencies. Sustainability is not easily studied. It requires consideration of both self-destructive and self-renewing tendencies within policies and practices, but these often work themselves out over long timescales, sometimes not knowable to researchers let alone likely to be taken into account by policymakers.

The current concept of flexible security (or flexicurity) is a good example of sustainable arrangements. The discourse from which flexicurity stems maintains that traditional measures for protecting workers from insecurity run a risk of impeding changes that demand labour flexibility; security measures therefore need to build in a capacity to avoid this trade-off.

\subsection{Governance and CLCs}

Collectivities within which life chances are collectively determined (CLCs) as defined here are the spaces within which security and protection from uncertainty are managed. Nation states are the principal units of study for this phenomenon in modern societies. This is partly for pragmatic reasons: most data are made available at national level; much existing research in this field reports results at this level. More substantively, it is the main level at which public policy is formulated. However, it is essential to recognize that nation states are not the only CLCs shaping regimes of uncertainty protection and security. Within the political realm, both the European Union (for European countries) and lower levels of formal government play a part. When we move to consider practices that either advance or retard sustainable security, we have to consider other institutions of which people are members, and which may affect their lives at least as much as public policy. Corporate pensions are an obvious example, and large corporations affect the security of various groups of their own employees and those of firms in their supply chains, as well as many self-employed sub-contractors, in many other ways too.

If CLCs play some part in allocating different levels of security and in pursuing sustainability, they must have some capacity for governance. The theory of governance, as developed by various scholars (Crouch 2006; Hollingsworth and Boyer 1997; Hollingsworth et al. 2002) provides a set of different forms to which individual empirical instances, as listed in the previous paragraph, can be related: market, corporate hierarchy, association, network, community, government, law.

\section{An analytical scheme for approaches to sustainable security}

To replace the narrow focus of current public policy concerns with flexibility and security, we need to construct an analytical scheme to accommodate the wide empirical diversity of both policies and practices, and modes of governance, as there can be no exhaustive or theoretically defined empirical list of these. Creative actors are constantly seeking, and often finding, new means to achieve security in fluctuating world markets, or bending to that purpose policies that were initially introduced for other reasons. We can move to a more analytical level by applying the "grammar of uncertainty management", the four main interrogatives, the questions: how? where? when? among whom? The first of these relates to the modes of governance. The other three concern the distribution of protection against uncertainty. 


\subsection{How? The means (governance) of distributing} uncertainty

The theory of governance has identified a number of key governance modes, at least one of which will be present within any individual CLC. It should be noted that in practice these governance modes often operate jointly within an area:

\subsubsection{Law}

The first field to which we look for governance is to government, or the state. In the case of states under the rule of law it is necessary to separate government and law as two separate components of the state, as government itself is subject to law. There may be a distinction, even a conflict, between current government preferences and the existing state of the law. This will be particularly important in fields subject to change and controversy, as is the case with sustainable security. Law is essential for the definition of employment statuses and their associated rights, and include the various forms of "soft law" that are emerging, particularly at the European level through the Open Method of Coordination.

\subsubsection{Governments}

Government is clearly a central form of governance in the whole field of employment and social policy, including some of its more extended aspects. When combined with law and some other institutions as the state, it is also the modern institution most commonly identified as a CLC. We also include here, in addition to national governments, regional and local levels and the European Union.

\subsubsection{Markets}

If law and government together constitute the forms of governance provided by the polity, there are also two forms of governance provided from within the economy. The first is the market, a CLC in which virtually everyone participates. Its main form of uncertainty management is to convert uncertainties into tradable risks. Individuals participate in the market with very unequal resources. Not only does the strength in the labour market of workers with different kinds of skill and capacity determine their ability to demand different levels of security guarantees from their employers, but the market (combined with corporate hierarchy and redistributed by government through fiscal means), determines income levels, the capacity to save from income being a major form of uncertainty protection. By themselves market forces do not categorize individuals into groups, but they may combine with other forms of governance (government, corporate hierarchy) to do so, as for example in employ- ers' classifications of manual and non-manual workers, frequently with different arrangements for pensions, sick leave, etc.

\subsubsection{Corporate hierarchies}

Following on from this, individual firms establish different packages of entitlements for different kinds of worker, extending not only to direct employees, but also to contract labour and to the firms in their supply chains and their workers. Many items in these packages have direct and major implications for the degree of protection from uncertainty that individuals can expect. Employing organizations can be important CLCs for individuals. Although they are directly concerned only with working life, the income and status derived from that affect most other areas of life too.

It is as important to distinguish between markets and corporate hierarchies as it is to do so between law and government. The distinction has been important in economic theory ever since the theory of the firm (Coase 1937) identified a difference between the firm as a simple nexus of markets and as an organization with the capacity to shape its use of markets, as in the distinction between external and internal labour markets. In more recent years the works of Williamson $(1975,1985)$ have firmly established markets and hierarchies as different forms of economic governance.

\subsubsection{Associations}

While, in modern societies, the polity and the economy are the principal sources of governance, other institutions in the wider society also regulate and manage areas of economic life. The most formal of these are associations, particularly important in the labour field through agreements reached between trade unions and employers' associations, or sometimes individual firms (Schmitter and Streeck 1985). Associations by themselves are very limited CLCs in modern economies, in contrast say with medieval guild society, where they were perhaps the most important of all for those covered by them. But relations between employers' associations and unions can be fundamental in regulating the most important issues relevant to sustainable security, from procedures for dismissal to the level of income. This governance operates at a number of levels, defining CLCs from local groups of firms to cross-national arrangements.

\subsubsection{Networks and communities}

Networks, as loose, informal forms of association, play an important role in modern economies, while the far tighter, but still informal units that we call communities, are more characteristic of traditional economies. Communities can 
be differentiated from networks by their tighter controls over members, extending across many areas of their lives, and their development of moral codes and norms. However, in the study of the governance of security and flexibility, communities of various kinds, particularly the family, are of considerable importance, and networks relatively weak. The only kinds of network sometimes relevant are those among firms that regulate employment relations and local supply chains in a more informal way than is found in associational governance.

\subsection{Where? When? Among whom?}

The study of inflation in the 1970s and 1980s made considerable use of the theory of collective action (Olson 1966). In particular it used Olson's (1982) analysis of how business associations and trade unions would tend to solve problems affecting them by dumping them (technically, externalizing) on to groups outside their own boundaries. In Olson's limiting case, groups whose members constituted the greater part of a defined whole could not externalize, and therefore developed means for resolving problems without burdening others. While the dynamics of the distribution of uncertainty are different from those surrounding inflation, the issue of externalization is central to both, as both concern CLCs, which define insiders and outsiders. Inflation research took it for granted that the associations at the heart of its analysis existed within nation states, and that the nation state constituted a universe within which the proportion of a wider community represented by a particular associational relationship could be assessed. Once we relativize the nation state, this analysis becomes more complex.

Four different approaches may be taken within a CLC to the management of uncertainty concerning the insider/outsider divide.

First, its members may try to externalize the insecurity that their members bear in the same way as was attempted with inflation, externalizing on to other communities, separate from them in place - in answer to the question "where?". In order to consider the scope that exists for doing this, let us make the initial assumption that nation states are the most powerful level of CLC. With the exception of privileged groups who are able to make the state take more notice of their interests than it does of others, governments can be expected to try to prevent internal communities (families, smaller firms, national-level associations and networks), from dumping within the nation state. Units that span jurisdictions may not be subject to such constraints; this is important in the case of multi-national firms. However, if we temporarily stay with nation states and governments, we have an institution with various possibilities for externalizing the insecurity problems of its members across place on to other nation states, or non-state external groups. In the absence of transnational regulation of some kind, a considerable amount of such "dumping" activity takes place.

Second, a similar process may take place in relation to time: a society of people living in a particular period may postpone resolution of various issues, leaving a later generation to face the burden - in answer to the question "when?". The location in time of human communities is considerably more complex than that concerning space. The CLC that constituted the nation of France in the 18th century is not the same as that of the 21 st century society that occupies the same territory. But this happens only gradually, as humans not only live across several decades, but also identify strongly with their children and probably at least one further generation. At what point does postponement of the resolution of a problem - say, the funding of a pension scheme cease to constitute sharing within the same entity, and become one of externalizing on to a future one? If we take a narrower view and examine the issue from the perspective of particular groups of decision-makers, externalization might be considered to start as soon as a new generation of office-holders arrives on the scene, a time lapse of perhaps only ten years. Unless time displacement is done over long periods of time, it may be difficult to distinguish from conflict between generations existing alongside each other, an issue that more properly belongs under the fourth possibility to be discussed below.

Third, members of a CLC may have to accept that they must internalize the uncertainty, minimizing it by sharing it through various collective measures - in answer to the question "among whom?".

Fourth, there is a distinction within this last approach and within the idea of "among whom?". CLCs may be internally stratified, and externalization may take the form of more powerful members requiring the less powerful to bear disproportionate shares of the burden of uncertainty - a kind of internal externalization. This may not necessarily occur as a result of conscious policy, but by repeated practice. In effect, sub-CLCs emerge within what seemed at first sight to be a single one.

Different policies and practices for the governance of economic uncertainty and the balancing of security and flexibility can therefore be analyzed in terms of:

I The main forms of governance involved.

II Relationship to the where, when and among whom questions (issues of place, time and internal distribution).

III Form of externalization, internalization or internal externalization involved; this addresses the degree of inequality produced by the policy or practice.

IV Sustainability probabilities associated with them. 
There can be no exhaustive list of policies and practices, as they are empirical, and capable of considerable multiplication as human beings tackle issues in new ways and find creative and innovative solutions, sometimes not even aware that they are doing so. The following discussion will embrace what appear to be the major examples of these in the present period. Research would do well to look for them, and in particular to look for typical combinations in which they seem to appear. But it will also need to look out for policies and practices not covered here, but which are relevant to how the balance between security and flexibility is achieved in any given society at any point in time.

Table 1 summarizes the principal terms of the following discussion. They are organized according to their principal modes of governance, any subsidiary modes being noted in the "Characteristics" column.

\subsubsection{Employment law}

First, employment law provides frameworks of employment rights and limits to them. During at least democratic periods, the main purpose of labour law has been to protect the rights of employees against employers who are regarded as being prima facie more powerful than they are (Davies and Freedland 2007; Knegt 2008). Labour law has therefore reinforced security, in some cases at the expense of flexibility. As such, it has come under sustained criticism from economists and others during recent years when employment sustainability has been seen to depend on increasing flexibility. The aim of much of this criticism has been to encourage labour law to accept a role in achieving a balance between security and flexibility. This is sometimes expressed in terms of degrees of deregulation, but deregulation nearly always requires some re-regulation, as maintenance of the market order itself requires a framework of rules (Majone 1990). A key development here in at least some countries has been the introduction of "reflexive regulation", or legally induced "voluntary" regulation to induce reductions in standards of protection, matching attempts in collective bargaining for derogations from sector standards by company-level negotiators.

\subsubsection{Social policies}

Prominent within the realm of formal public policy is the delivery of various services. These have a wide variety of implications for security, not all of them obvious. In the first instance, directly provided services remove certain important areas of activity from the market, providing security of continuing access to them during times of economic difficulty. Especially among lower-paid workers, this can relieve the strain of labour-market insecurity, possibly enabling them to accept more uncertainty in that market than coun- terparts in societies where social service provision is much lower

From this has flowed a secondary, originally accidental consequence, which has its own implications for economic uncertainty. Public services offered in kind include a range of care services: child care, sickness care, elderly care. Where these services are provided by the market, they tend to be too expensive for people on modest incomes, so there is under-provision. They are often provided within the family, primarily by women. In that case the provision exists, but not as part of the labour market. Where government provides or subsidizes services, they are still primarily provided by women, but within the labour force, generating jobs, incomes, and therefore purchasing power. Further, other women relieved of family caring roles by the availability of the public services, enter other parts of the labour force. This leads to a kind of femino-multiplier of job creation. At least within Europe, those economies that provide high levels of publicly funded direct services have higher levels of female and aggregate employment (Esping-Andersen 1999). This has had a number of implications for sustainability. To the extent that populations live in male/female partnerships, the increase in female participation has brought the stability of two separate employment incomes to households. Given the differences in the sectors in which men and women are likely to work (with women less likely to work in the exposed sectors), the dependence of individual households on individual industries and on the private market will often be reduced. Most important, the femino-multiplier has both created employment and, as a consequence, taxation revenues, which make possible further public-service provision.

\subsubsection{Improving skill levels and employability}

A form of security provision that is fully compatible with the free market is when individuals insure against future labour-market risk by investing in their own educational opportunities, including when they engage in mid-career education and training in order to anticipate future adverse labour-market change affecting their current employment. While wealthy individuals might do this unaided, this is a field with considerable government involvement; there is considered to be a collective interest in workforce upskilling, which extends beyond individuals' perceptions of their own interests; it is very difficult for individuals to anticipate future labour-market skill changes. Given that most education involves young people, it is also a form of future investment that requires a major contribution from the family. The time-related nature of the distributions involved here is relatively short-term, and they are therefore turned into distributions among contemporaries. Whether and among whom they externalize depends on the identity 
Table 1 Potential analytical scheme for regimes of uncertainty distribution

\begin{tabular}{|c|c|c|}
\hline $\begin{array}{l}\text { Principal } \\
\text { governance } \\
\text { modes }\end{array}$ & Policies and practices & Characteristics \\
\hline Law & Employment law & $\begin{array}{ll}\text { I: } & \text { none } \\
\text { II: } & \text { internal distribution } \\
\text { III: } & \text { ranging from sharing to internally externalizing } \\
\text { IV: } & \text { dependent on economic viability of protection }\end{array}$ \\
\hline \multirow[t]{4}{*}{$\begin{array}{l}\text { Mainly } \\
\text { government }\end{array}$} & $\begin{array}{l}\text { Social policies directly } \\
\text { delivering services }\end{array}$ & $\begin{array}{l}\text { I: family } \\
\text { II: internal distribution } \\
\text { III: sharing } \\
\text { IV: dependent on funding arrangements }\end{array}$ \\
\hline & $\begin{array}{l}\text { Advancement of } \\
\text { population's skill and } \\
\text { employability level }\end{array}$ & $\begin{array}{l}\text { I: family, market } \\
\text { II: place; internal distribution } \\
\text { III: externalizing on to economies without advancing skills; internally externalizing } \\
\text { at point of input on to families with difficulties in access; at output on to workforce } \\
\text { with lower education achievements } \\
\text { IV: sustainable, provided demand exists for skills acquired; can be internally positive } \\
\text { sum if leads to growth in supply of high-skilled jobs }\end{array}$ \\
\hline & $\begin{array}{l}\text { Public promotion/ } \\
\text { protection of sectors } \\
\text { and production locations } \\
\text { perceived to be of } \\
\text { strategic importance; } \\
\text { public employment }\end{array}$ & $\begin{array}{l}\text { I: corporate hierarchies } \\
\text { II: place; also internal distribution } \\
\text { III: externalizing on to economies with similar industries but without support; } \\
\text { internally ranging from sharing to internally externalizing } \\
\text { IV: dependent on long-term market viability of strategies, and on character of activities } \\
\text { encouraged }\end{array}$ \\
\hline & $\begin{array}{l}\text { Government demand } \\
\text { management }\end{array}$ & $\begin{array}{l}\text { I: market } \\
\text { II: time; internal distribution } \\
\text { III: sharing } \\
\text { IV: dependent on government discipline }\end{array}$ \\
\hline $\begin{array}{l}\text { Government, } \\
\text { market, } \\
\text { corporate } \\
\text { hierarchy }\end{array}$ & $\begin{array}{l}\text { Insurance and } \\
\text { pensions }\end{array}$ & $\begin{array}{l}\text { I: associations } \\
\text { II: internal distribution; time } \\
\text { III: shared within insured community; internal externalization through inequalities in } \\
\\
\text { IV: depess to schemes } \\
\text { IV: dent on funding design and labour-market incentives included }\end{array}$ \\
\hline \multirow[t]{4}{*}{$\begin{array}{l}\text { Mainly } \\
\text { market }\end{array}$} & $\begin{array}{l}\text { Trading relationships } \\
\text { among nation states } \\
\text { with different export } \\
\text { and import relationships }\end{array}$ & $\begin{array}{l}\text { I: corporate hierarchy } \\
\text { II: place } \\
\text { III: externalizing, with insecurity normally concentrated in export economies } \\
\text { IV: dependent on long-term impact on the two sets of economies, and on character } \\
\text { of production encouraged }\end{array}$ \\
\hline & $\begin{array}{l}\text { Credit to sustain mass } \\
\text { consumption }\end{array}$ & $\begin{array}{l}\text { I: possibly government } \\
\text { II: time; internal distribution } \\
\text { III: externalizing on to future if confidence collapses } \\
\text { IV: unsustainable in long term }\end{array}$ \\
\hline & $\begin{array}{l}\text { Locally clustered } \\
\text { economic sectors }\end{array}$ & $\begin{array}{l}\text { I: community } \\
\text { II: internal distribution } \\
\text { III: ranging from sharing to internally externalizing, dependent on relation of clusters } \\
\text { to rest of economy } \\
\text { IV: dependent on economic viability of sectors }\end{array}$ \\
\hline & Shadow economy & $\begin{array}{ll}\text { I: } & \text { community } \\
\text { II: internal distribution } \\
\text { III: internally externalizing, concentrating uncertainty on those in shadow economy } \\
\text { IV: dependent on legal circumstances }\end{array}$ \\
\hline $\begin{array}{l}\text { Mainly } \\
\text { corporate } \\
\text { hierarchy }\end{array}$ & $\begin{array}{l}\text { Managerial organization } \\
\text { of activities offering } \\
\text { varying degrees of security } \\
\text { among different countries } \\
\text { and regions; supply chains }\end{array}$ & $\begin{array}{l}\text { I: market } \\
\text { II: place; internal distribution } \\
\text { III: externalizing or internally externalizing on to economies/regions on margins } \\
\text { of corporate strategy } \\
\text { IV: dependent on long-term viability of inequalities produced among countries/regions }\end{array}$ \\
\hline
\end{tabular}


Table 1 Continued

\begin{tabular}{|c|c|c|}
\hline $\begin{array}{l}\text { Principal } \\
\text { governance } \\
\text { modes }\end{array}$ & Policies and practices & Characteristics \\
\hline & $\begin{array}{l}\text { Internal labour markets } \\
\text { and organization of work }\end{array}$ & $\begin{array}{l}\text { I: market, associations, communities } \\
\text { II: internal distribution } \\
\text { III: internally externalizing on to marginal employee groups/contract workers } \\
\text { IV: sustainability dependent on political situation }\end{array}$ \\
\hline Associations & Collective bargaining & $\begin{array}{l}\text { I: market } \\
\text { II: internal distribution; place } \\
\text { III: ranging from sharing to internally externalizing, depending on inclusiveness and } \\
\text { arrangements; can be externalizing on to other countries (competitive corporatism) } \\
\text { IV: dependent on long-term viability of co-ordination strategies and underlying } \\
\text { product market developments }\end{array}$ \\
\hline $\begin{array}{l}\text { Mainly } \\
\text { community } \\
\text { (including } \\
\text { family) }\end{array}$ & $\begin{array}{l}\text { Inter-generational } \\
\text { transfers and support }\end{array}$ & $\begin{array}{l}\text { I: family; possibly assisted by government via social insurance } \\
\text { II: time; internal distribution } \\
\text { III: shared within family; internally externalizing on to families with low resources } \\
\text { IV: sustainable; but party dependent on long-term sustainability of social insurance } \\
\text { funding design }\end{array}$ \\
\hline Various & $\begin{array}{l}\text { Protection of } \\
\text { property-owning } \\
\text { elites from labour- } \\
\text { market uncertainty }\end{array}$ & $\begin{array}{l}\text { I: various } \\
\text { II: internal distribution } \\
\text { III: internally externalizing, with strongly unequal inputs and outcomes } \\
\text { IV: dependent on political situation }\end{array}$ \\
\hline
\end{tabular}

Key:

I Subsidiary forms of governance involved;

II Relationship to issues of place, time and internal distribution;

III Form of externalization, internalization or internal externalization involved;

IV Sustainability probabilities.

of the CLCs managing them. If it is implemented by families, it is likely to reproduce and enhance existing social inequalities; if by the state, the outcome depends on the characteristics of the scheme adopted.

Social policy measures to stimulate labour-force participation, or active labour-market policy (ALMP), also need to be considered here (for a recent survey of different labour-market policy measures being implemented in Europe, see Eurostat 2009, pp. 288-291). In many countries many transfer payments are increasingly being linked to ALMP measures which are in turn often linked to official encouragement of training and education. These are responses to fears about the sustainability of social transfer regimes alone. There is an important triangle linking social insurance and social security, ALMP and personal investment in education. To the extent that ALMP policies are linked to transfers, they take the form of "workfare" threatening loss of benefit if advantage is not taken of activation opportunities. If they are more linked to improved access to investment in personal futures, we may speak of Danish and Dutch "flexicurity" measures (Muffels et al. 2008; Rogowski 2008; Wilthagen 2002; Wilthagen and Tros 2004), though the distinction is far from clear. These systems are all based on sharing within a community, but with possible inegalitarian effects where ability to benefit from schemes is unevenly distributed. They are usually designed with high sustainability.

\subsubsection{Public promotion of sectors, etc.}

A wide range of other policies and practices use combinations of government and individual corporate actions to try to provide security for workers in selected industries or parts of a country. The most classic measures here are outright protectionism and the promotion of "national champion" companies. The latter was a strategy particularly favoured in France and Italy after World War II, as an alternative to Keynesianism (Hayward 1995). It is an approach that generates divisions between insiders (in the protected industries) and outsiders (in the non-strategic industries, usually light manufacturing and sectors dominated by small firms). In Italy in particular it was a kind of mirror-image to industrial districts (see below): the government favoured certain large-scale Fordist industries (motor vehicles, steel, etc.), leaving clothing, textiles and similar industries concentrated in small firms and without central government interest. The clustered small and medium-sized enterprises (SMEs) forged their own form of security as will be discussed, while government support provided security for 
the favoured industries and firms. The burden of uncertainty was borne by industries outside these two groups.

National champion strategies have been under considerable pressure from EU and WTO competition rules in recent decades, their sustainability in the face of international competition is dubious, and they seemed to be disappearing. However, they have re-emerged in slightly different form with the "rescue operations" being launched, particularly in the UK and USA, in the face of the current crisis. First, the operation was limited to firms in the financial sector (certainly a champion industry for the UK and USA), but it was then extended to motor vehicles and some other industries. Included here are also government stimuli to consumption targeted at specific industries (e.g. rotamozione policies to encourage the replacement of old motor vehicles, adopted in Germany, Italy and the UK). It is important to study, not just which industries are chosen for and which rejected from such policies, creating externalities both between and within countries, but also their implications for security of the workforces, which cannot be automatically assumed. Sustainability is also clearly an issue.

More subtle policies also survive. In the same way that governments have tried to protect certain industries, they may do something similar for specific geographical areas - cities, or whole regions. Policies to target infrastructure projects on, or attract international events to, particular areas do not fall foul of competition law. These policies grew in importance as those of the type just discussed were challenged. They can be of two kinds, which tend to be mutually contradictory within an individual nation state. They can be targeted at the development of backward regions or the regeneration of declining ones; or they can be used further to strengthen leading areas - "champion cities" - to equip them for global competition (OECD 2006b). State actors at various levels, from the EU to local authorities, become involved in actions of this kind.

Another protected sector is usually public service. Since its products are not immediately subject to fluctuations in product markets, it usually offers more security to its employees than much of the private sector. Whether this creates internal externalization issues and problems of sustainability will depend on the arguments noted above in connection with the possible stabilizing and multiplier role played by this sector.

These policies have various place and internal distribution implications. Many of them (though not public-service employment) seek to protect or promote employment in one country at the expense of others who have not developed the same measures. They have similar consequences for sectors and regions not being favoured by policy. These may be more difficult to unravel, depending on whether there is a zero-sum relationship between the favoured and unfavour- ed sectors, or whether there are multiplier or trickle-down effects linking them, as mentioned in connection with public services. Sustainability will depend partly on arrangements having these effects.

\subsubsection{Demand management}

In Keynesian demand management government acts alongside the market. It uses its own spending to boost the economy to avert recession and to cool the economy during inflation. By damping the impact of the trade cycle it seeks to reduce the degree of insecurity in the labour market. This was the main macro-economic strategy pursued in the USA, the UK and the Nordic countries for the first three decades after World War II. As discussed in the historical introduction, the approach fell into relative disuse after it was considered to have worsened the inflationary crises of the 1970s, and thus to have become unsustainable. This change precipitated the chain of developments that led eventually to the questioning of employment security regimes that emerged during that same post-war period, but it remains among the policy devices that governments still use. It operates over time, using government's own spending to smooth trade cycles, and its impact within a society tends to be egalitarian. But these characteristics and its sustainability depend on governments being willing to act counter-cyclically during both parts of the trade cycle, and not only to encourage demand during potential recessions.

\subsubsection{Insurance}

As already noted, within markets it is possible to assign probabilities to uncertainties and then to turn them into tradable risks; this is a form of distribution of the costs of uncertainty over time. In a pure market economy, workers and others would insure themselves against risks that might affect their security. But, important though the insurance model is for many purposes, it is not common for the mass of a workforce to insure privately against labour-market risk. Such behaviour is vulnerable to three market failures. First, the costs of such insurance are likely to take the poor to very low levels of subsistence, leading them to place a small improvement in comforts today over provision for the future. Second, more generally than this, individuals are myopic in relation to likely major economic developments and would find it hard to make rational calculations concerning their insurance needs. Third, the classic reasons for breakdown of insurance markets - adverse selection and moral hazard are likely to be a severe problem, particularly for insurance against sickness and unemployment. Finally, given that the collective interest in achieving sustainable security is greater than that of any individual, individuals must be expected to 
take precautions below the level needed for this collective purpose.

This is therefore an area where governments have intervened. They have done so by providing social insurance; the most direct form of government intervention to seek to reduce economic uncertainty is the provision of social insurance systems, usually reinforced by social security measures. In the former, management of schemes is often shared with associational governance. These systems are limited to distribution within the risk community identified, though they also operate across the time dimension as does all insurance. In principle they are relatively egalitarian, but systems comprising schemes for different occupational groups have certain inegalitarian effects. Also, many workers may be left outside the scope of all insurance schemes. Whether they are sustainable depends on their internal funding arrangements and on the incentives they give to people capable of working to return to the labour market.

The market has been more active in the pensions part of social insurance. In fact, within pensions we see four strong governance modes: government, in the form of public social insurance; associational governance in those countries and sectors where pension funds are typically managed by unions and associations of employers; the corporate hierarchy in the case of company and occupational pension schemes not subject to associational governance; and the market in the personal pensions sector.

\subsubsection{International trading relationships}

Until now, with the possible exception of private insurance, we have considered the issues that are usually addressed in discussions of security, flexibility and other labour-market questions. We now turn to some of the less obvious, but possibly more important contextual factors that determine the levels of economic uncertainty confronted by different work forces. We first consider the fact that security can be gained within a given location by pushing uncertainty on to other places, which lack the capacity to take counter action. These differences of location within the global division of labour should be fundamental to any attempts to establish typologies of national "social models", though they are usually completely ignored by these. Such typologies normally treat all countries as though they are more or less equal units, examples of the same phenomenon. But once we appreciate that countries are not separate units, but nodes within a hierarchized network (as in Wallerstein's world system theory (Wallerstein 1974)), and occupying very different positions within that network, the form of analysis we attempt changes very considerably.

When a country's labour force specializes in export markets, its security is heavily dependent on fluctuations in world trade (unless the export markets concerned have low elasticities, in which case the position may be an exceptionally favourable one). Such a system was dominant in the Bonn Republic during the early years of post-war recovery in the 1940s and 1950s. German workers were very poor, but the Second World War victor countries and various neutrals were on a different economic path and provided mass markets for German goods. German workers are no longer poor, but the export orientation of economic policy remains, with a reluctance to boost the economy through internal demand. Until recent years this has led in turn to relatively low levels of both internally traded and publicly provided direct services, with as a consequence a poorly developed femino-multiplier.

Many developing countries in the Far East, and also in central and eastern Europe are in such a position today, though this has recently run into a crisis in several of the latter, which are running serious trade deficits. The other side of the coin of the export economy is the way in which some countries engage less in the production of labour-intensive goods for international markets and more in domestically consumed services or exports (mainly financial and some other services) that do not require a large domestic work force. Any declines in domestic consumption in such nation states will be largely at the expense of workers in other countries' export sectors, enabling a more rapid recovery from the domestic recession. For countries to be able to take advantage of this, they must have a prior position of higher levels of income than the producing countries, and they must have means of financing their trade deficits. This is therefore usually an approach that is available only to financially powerful countries, with capacity to fund long-term negative trade balances, perhaps backed also by military and political power.

In general, an economy able to sustain long-term trade deficits will confront fewer employment fluctuations, and therefore be under less political pressure to provide security measures, than an open export economy. This is clearly an example of a form of security distribution that operates across countries. Whether it is sustainable depends on the continuing terms of the balance of trade and the political situation in export-oriented economies.

\subsubsection{Credit-based economies}

A market-driven practice that has developed in some countries in recent years has been to separate individuals' consumption behaviour from their labour-market income through extensive unsecured credit, usually mortgage debt but also credit cards. Although these practices developed solely for reasons associated with the financial sector's search for profits, it had the unanticipated effect of reducing the stress placed on individuals' concern for labour-market security as such. The practice developed in a major way in 
a number of countries, principally the USA, the UK, Iceland and Ireland. It required three conditions to grow. The first was a general rise in home ownership funded by mortgages, giving individuals on moderate and even low incomes forms of collateral partly independent of labour-market position. The second was the growth of secondary financial markets that enabled the risks associated with housing and other forms of debt (such as credit cards, which were growing during the same period) to be shared among an increasing number of players in the financial markets. The third was the global deregulation of financial markets, which enabled more and more players and holders of different kinds of funds to enter these markets. Eventually risks were being shared so widely that collateral requirements on mortgages, credit cards and other forms of debt became nugatory. The sums that people could borrow both rose strongly and became detached from their labour-market positions.

The system can be seen as a market-generated functional equivalent of government demand management - a form of "house price Keynesianism" (Hay et al. 2008), or "privatized Keynesianism" (Bellofiore and Halevi 2009; Crouch 2009). Whereas under straight Keynesianism government sustains mass demand through its own borrowing, here the borrowing is undertaken by individuals themselves, incurring mass individual debt. Financial irresponsibility curiously became a collective good. This element - the maintenance of consumer confidence - has meant that public policy eventually became involved in sustaining it. The model depends on continued housing market buoyancy, and governments may intervene to ensure this situation. This regime is vulnerable to eventual questioning of the value of the risks being traded, as was demonstrated in 2007-2008 in the global financial crisis. It requires certain institutional preconditions: widespread owner-occupation and constantly rising house prices; extensive, unregulated or lightly regulated financial markets, especially secondary and derivatives markets.

The sustainability of this practice is highly doubtful, not only because it eventually caused the financial collapse of 2007-2009, but because, even more than straightforward Keynesianism before it, it ceased to act counter-cyclically. Initially it may have acted counter-cyclically in enabling US citizens to be confident consumers despite their insecure labour-market positions and static or declining employment incomes during the 1990s, but when there was a widespread loss of confidence in the banks there was a simultaneous and therefore pro-cyclical collapse of both consumer spending and credit.

\subsubsection{Clustered economies}

A particular market-driven form of employment security often exists within industrial districts and other areas of local economic specialism, where large numbers of firms, particularly but not solely SMEs, in related areas of activity, cluster within geographical areas. Major instances are found in the Italian industrial districts (Pyke et al. 1990), in Denmark (Kristensen et al. 1999) and in California (Kenney 2000). Such clusters provide security at a level above that of the individual enterprise. Workers perceive that they have a diversity of employment opportunities available to them within a geographical range and within social networks. The fragility of individual firms does not therefore necessarily threaten employment and income levels of either the economic activities or the areas concerned.

While such situations provide sustainable solutions to the security issue, they have two weaknesses as general models. First, SME clusters are normally found in niche economies and are not likely to exist at a national level. They are most likely to thrive in activities involving new scientific knowledge or fashion-conscious design, where there are particular gains to be had from innovation based on tacit knowledge. Second, districts and other clustered activities move from being particularly resilient to being particularly brittle when there is a collapse of the whole sector in which the area is specializing, as this frequently leaves few employment opportunities, leading to a crisis of confidence and a decline in purchasing power. Their sustainability is therefore highly contingent.

\subsubsection{Shadow economy}

Sometimes economic clusters are part of the shadow economy, though that concept is more extensive than this. Most studies of labour protection regimes and flexibility usually consider formal rules and assume that these are effectively implemented. In doing so they miss both part of the reality of labour-market regulation and important numbers of employed persons, as the shadow economy does not appear in any statistics (Schneider 2007). It is important that research take full account of the size and place of this economy, because it forms a major device for segmenting work forces, those in the shadow economy normally not benefiting from any of the formal security measures available to the mainstream work force. Insecurity may therefore be externalized on to these workers, providing a certain form of flexibility. In developing economies illegal work and firms without a legal existence are the norm. Within Europe there are important concentrations of the shadow economy in the south and, in particular, the CEE countries. But it is a part of the reality in all economies.

Immigrant - and even some settled ethnic minority workers often provide insecure work forces for the shadow economy, particularly illegal immigrants. They are sometimes supported in their general state of high insecurity through support from their own community institutions. Their positions are in general far less secure and less well 
remunerated than the majority population, but while they remain de facto segregated from that majority, their lack of security does not threaten that of the majority.

\subsubsection{Managerial organization of activities}

The corporate hierarchies of major companies, acting alongside the market, have an impact on the spatial distribution of security when they devise a strategy for locating jobs with different levels of security in different parts of the world, or perhaps regions of a large nation state. Individual corporate practice, alongside other governance forms, is also important in structuring different security outcomes for different parts of the work force within a society through the way in which it defines different work categories and their attendant privileges. Both international and internal practices extend from a firm's own employees to its supply chains.

Management strategy is concerned with maximizing the interests of the firm; the geographical distribution of degrees of security and insecurity within different societies that flow from its actions is just a by-product, but the social implications and resulting inequalities of this can be extensive. The sustainability of the approach is difficult to establish, but further complications are introduced if firms use their geographical flexibility to create labour insecurity in all countries in which they operate, in the stereotypical "race to the bottom" in labour standards. From a European perspective there are differences between geographical flexibility that extends to other parts of the world, and that contained within the basic rules of EU social and labour policy. This has of course become particularly important since the entry of the new member states in central and eastern Europe. This has led, not merely to competition between Europe and the rest of the world, but - at least as importantly - competition within Europe between different member states, different regions, and, by implication, different social models.

Within internal markets explicit or implicit guarantees of employment and/or stable incomes are offered to parts of the work force, often combined with having other parts in the external market through sub-contracting and supply chains. The protection offered to privileged groups or, more generally, to insiders is partly dependent on outsiders bearing the brunt of any difficulty encountered in maintaining the stability guarantee given major market fluctuations. Unless this is the case, these policies have not resolved the confrontation between flexibility and security, but have sacrificed flexibility. In explicit cases, employers distinguish between categories of workers who enjoy guarantees and those who are regarded as temporary or casual. This has been a central feature of large Japanese corporations, and also of German firms distinguishing between Stamm- (core) and Randbelegschaften (marginal workforces). The general theme has long been recognized by students of the labour market as "segmentation" (Berger and Piore 1979; Loveridge and Mok 1979).

More implicit policies take the form of widespread understandings that certain principles will be followed in cases of redundancy or short-time working, such as tacit understandings that women, or immigrants, or very old workers will have the weakest claims to tenure. Anti-discrimination and equal opportunities legislation has often restricted the scope for such explicit practices. Nevertheless, demographic distinctions might produce implicit distinctions. For example, workers of different ages, ethnicities, genders might be typically found working for sub-contractors rather than in leading firms themselves. Use can also be made of illegal workers (usually illegal immigrants) in order to concentrate insecurity in particular groups and provide reassurance to others. All such cases of distinction between secure and insecure workers enable core workers to remain confident consumers while labour markets become flexible, but at the expense of potentially low confidence among the outsiders. The sustainability of these practices may depend on support from other CLCs to which insecure categories of workers might belong. This topic will therefore appear again below.

\subsubsection{Collective bargaining}

Associational governance, here collective bargaining between trade unions and either individual firms or groups of employers, is normally associated with reinforcing labourmarket security, and is often criticized for doing so at the expense of flexibility and therefore in unsustainable ways. Alternatively, it may achieve a balance between security and flexibility by enforcing distinctions between insiders and outsiders. However, because collective bargaining involves negotiation and is capable of operating at a strategic level, it is possible for the participants in bargaining to trade flexibility and security. This can happen under a variety of contexts, but not all. For example, when bargaining takes place at the level of the individual firm, workers' representatives may have to trade the short-term protection of their members' security against possible needs for flexibility if the firm is to survive and thrive. This is generally known as concession bargaining. Alternatively, unions may protect the positions of current insiders at the expense of outsiders, through such formulae as "first in, last out" (which tends to discriminate against young workers, as discussed above), or discriminating between a permanent core work force and one on temporary contracts. Economists' theories of trade unions regard these practices as axiomatic to how unions operate (e.g. Blanchard and Summers 1986; Rueda 2005, 2007). This is because they assume a model of company-level bargaining (as in the US and Japanese cases). But a union with members across an entire industry or other generally defined labour market is likely to see such 
arrangements as leading eventually to employers' preferring the creation of temporary and insecure contracts over stable ones. For example, in Spain, the European country where most use is made of temporary contracts, unions oppose the strategy (Talani and Cerviño 2003).

Above individual firm level, collective bargaining may be involved in explicit flexibility/security trade-offs, but only where bargaining takes a co-ordinated form, with unions and employers associations being so structured that they cannot easily avoid taking responsibility for macro-economic consequences of their actions, including a significant role for unions and associations representing the exposed sector of the economy (Traxler 2003; Traxler et al. 2001; Traxler et al. 2008). This takes us back to something similar to the politics of the counter-inflation strategy in the 1970s. Different forms of coordination will have different implications for different patterns of flexibility and security: for example, the difference between vertical and horizontal coordination and the role of sectoral or company-level negotiations. Some forms are more consistent than others with the maintenance of security traditionally associated with multiemployer, sector (or inter-sector) bargaining.

A different attempt at a kind of "collective privatized Keynesianism" has been made by German unions. They have sought to use collective bargaining counter-cyclically, accepting restraint and the priority of competitiveness during periods of rising costs, but seeking to boost consumption through high wages during recessions (Erne 2008).

Collective bargaining may also make a contribution to the export of insecurity, when it takes the form of "competitive corporatism" (Rhodes 2001), with bargaining seeking to contain wage costs in the home country in order to improve competitive position against firms and workers in other countries.

\subsubsection{Inter-generational transfers and support}

Family also appears prominently as an institution for managing security balances among individuals and over time, outside the scope of the market. It is an important channel for inter-generational financial transfers, for example in housing finance. While elements of its role can be seen in most societies, there is considerable diversity. There is also a considerable difference in mean ages for young people leaving the parental home - ranging from the early 20 s in northwest Europe to over 30 in the south-west. This is relevant to different ways in which young people are helped through difficult labour-market situations in different societies. Social norms about family obligations play a part in determining these differences, but they are sometimes supported by social and fiscal policy (Jurado Guerrero 1999). Again, as this becomes a form of governance among contemporaries its impact depends on differences in access to the relevant resources among different families.

Family has particular implications for the labour-market position of women. They often occupy insecure places in the labour market, but may be deemed to have a primary identity as working within the family, with security provided by a husband or other male "bread winner". Studies of social policy and redistribution usually concentrate on relations between markets and state provision, leaving out these activities of the family. While its welfare role was historically considerably reduced by the rise of the welfare state, it remains fundamental for the living standards and security of persons not participating in the labour market, whether because of age, disability, household responsibilities or unemployment. There is also considerable diversity in the relationship between families, welfare states and commercial activities and the provision of care services. Family members both provide and receive care, in both cases affecting the labour market. This kind of role for the family perpetuates inequalities across generations, and there may be doubts about its sustainability. It depends today on certain incentives from social policy and transfer payments (mainly pensions), and certain forms of gender relations. In some countries the family's capacity to support its members through insecurity depends on the house price phenomenon discussed above, with older generations being able to stand by younger ones because of the security of their property assets.

\subsubsection{Protected elites}

Historically the most important form of security distribution has been a combined product of several modes of governance: market, government, law, community. This is when privileged minorities in a population are protected from economic insecurity by being made independent of labourand product-market fluctuations - typically aristocracies, rentiers and others with large stores of property. Various combinations of political decisions and the market produce these outcomes. Consumption in such societies is heavily concentrated among these groups. This is the system that predominated in most societies unless and until mass domestic consumer markets developed, for example most pre-industrial societies and those in the early stages of industrialization (like China today). It was partly cast aside by capitalist economies when they entered the Fordist period of mass production at various points during the 20th century, though privileged groups usually retain better access to political decision-makers than the majority of populations.

As a regime the elite privilege model presents two principal sustainability problems. First, without mass markets there are severe limits to possibilities for economic growth; this is in practice often resolved through a combination of this regime with that discussed above of export dominance. 
Second, it depends on the economic, social and political exclusion of the mass of the population, which probably requires an extensive apparatus of suppression.

However, its approach - the flexible labour force has sufficiently weak purchasing power for its lack of consumer confidence not to present a macro-economic problem - can apply to poor minorities within modern work forces. We have seen this above in relation to the shadow economy and labour-market segmentation, in particular when these make use of ethnic or other category forms of distinction within populations. As noted at several points above, various combinations of public policy, market forces, the practice of individual corporations, and the operation of communities can produce and make use of these distinctions. In particular, women, more specifically mothers, are often regarded as not being in the same labour-force position as men; their redundancy, reduced hours or periods of unemployment are not seen as problematic, and their incomes tend to be low.

\section{Uses of the approach}

Such an exercise as the above provides an expanded approach to the study of labour and welfare policy regimes - assuming that groups of policies and practices remain together in stable ensembles long enough to justify the title "regime"; it is possible that in some cases, including some in central and eastern Europe, one will find a shifting array of barely linked elements. Analysis should not immediately turn to the state as the necessary locus of any protections against market uncertainty, but should be open to a wide range of institutional possibilities, taking seriously the roles of a range of CLCs and of different governance modes. It is further possible and necessary to consider changes in regimes over time as well as synchronic comparisons among countries. This will enable us to identify any common trends among cases. We can focus on changes in forms of governance, in playing off time, place and distributional dimensions, in degrees of externalization, and in degrees of sustainability.

Regimes in the sense being used here have to be understood as collections of policies and practices, which are the outcomes of various actions that were not necessarily ever planned to exist together, but which have found various complementarities and elective affinities over time. Often particular outcomes resulted from major conflicts, in which the "winners" were associated with certain practices, these not being necessarily optimal or even particularly coherent. Such a regime should not be understood as an entity to be explained by functionalist theory or just taken for granted as existing. It is a human construction, probably the accidental outcome of masses of different actions over long periods of time and therefore difficult to change and subject to path de- pendency forces. But it continues to require human action to sustain it, which also means that it is vulnerable to constant small adjustments, sometimes larger ones. Some of these will be deliberate, even strategic; others will be minor and carried out with little thought for larger consequences, but even some of these might retrospectively be incorporated within someone's repertoire of planned action.

Regimes are therefore always subject to change and are either the outcomes of, or become incorporated in, policy. With the exception of completely autocratic regimes, it should also be assumed that a variety of different interests and forces produce the actions that shape and change regimes. Analysis therefore needs to identify these and trace their different impacts. It is by no means the case that all actors involved operate within the public policy-making realm; regimes will therefore be the outcome of both public and private policy-makers' actions. It also follows that regimes, as the outcomes of such heterogeneity, are likely to embody internal incongruence, even unresolved contradictions.

A first stage in the application of this approach is to analyze which groups of policies and practices relevant to sustainable security, and with which relative importance, are found within individual national cases, and how these have changed over time within them. Table 1 gives us a provisional range of policies and practices, and one task will be to establish if some of these tend to be found grouped together. This will possibly, but not necessarily, enable us to form groupings of countries, which could be compared with existing groupings to be found in the literature on comparative welfare states and industrial relations systems. These existing models are normally based on a far more restricted range of institutions than proposed above. Eurostat (2007, Chap. 3) continue to find an amended version of EspingAndersen's (1990) scheme highly applicable, dividing European countries into his three groupings of Anglo-Saxon, Continental, Nordic, but adding (as has been done in much research) a Mediterranean group comprising some of his Continentals, and the EU member states of central and eastern Europe. However, to achieve this they move Italy or Greece into central and eastern Europe, and the Netherlands into the Nordic zone. Further, they are still focussing on the micro-level of flexibility defined by the deployment of workers. To what extent and in which ways does the picture change when account is taken of the wider range of issues considered here?

The existing models also tend to be grounded in specific historical moments, which are deemed to establish path dependencies from which subsequent history simply realizes a trajectory. For example, Esping-Andersen's (1990) approach starts with a stylized history of the class conflicts present during initial industrialization. The continuing explanatory power of his framework (somewhat modified by other authors to take account of southern Europe (Ferrera 
1996; Naldini 1999) testifies to the path dependence established at that crucial moment. This does, however, raise the question: have the shifts to post-industrial employment and economic globalization produced no disturbances to that initial source of difference? Use of an expanded model of practice and policy regimes, as outlined above, might enable us to answer this question in a more detailed and nuanced way.

Second, it is important to examine change over time within the cases, as some types and combinations of types might be fading in significance while others are becoming more prominent in any given country, or more generally. This would strengthen our capacity to identify how Europe's social models are evolving. To the extent that it is possible, we need to extend this approach to a different but related point: observing how the inter-temporal relationship between flexibility today and security tomorrow is developing. For example, recent pension reforms in many countries have had negative implications for expected future security for young workers, especially in labour markets with high levels of temporary and precarious employment.

Third, once we have discovered whether different types tend to be found together, or tend to "repel" each other, we may be able to construct theories to account for such associations, which might also assist in relating any observed differences to different balances of class and other interests in the development of policies and practices. It will also be possible to determine how the various types vary in their impact when they appear in different combinations. For example, low formal job security operates very differently in the Danish context of a strong welfare state, strong trade unions, distinctive niche export products and industrial districts than in a country that lacks these characteristics. A further example would be the twofold role played by Italian government attempts to stimulate employment in the public sector in the Mezzogiorno (Burroni 2009). The growth in jobs was not directly connected with the demand of public services. The policy created stability and security for an important part of the population, but by not matching employment growth to the demand for services, it produced a high level of inefficiency in public services and had no multiplier effects. This negatively influenced the production of local collective competition goods for private firms. As a result these firms were weakened in international competition, dramatically reducing the security of workers.

Research in the social and labour field can no longer be carried on in isolation from the issue of sustainability. This has two meanings: the sustainability of institutions themselves and the literal meaning of environmental sustainability. It is probably best to tackle these in terms of entire ensembles of policies and practices rather than appraise them separately, given that it is as ensembles that they will acquire practical form. Appraisals of the relative "success" of different ensembles will need to include sustainability measures as well as the more usual ones of economic growth and employment. For example, it would be useful to compare the overall costs and benefits of different national choices between corporate bailouts and public transfers and services as means of tackling the current crisis. Thinking more specifically of the environment, we need to pay attention to the fact that strategies that depend very much on expanding international trade are also involved in the export of products from polluting industries.

Challenges are presented by the different forms of governance at work in the various policy and practice fields. The crisis of the Keynesian model was often seen as a crisis for associational governance (or neo-corporatism), and an advance for reliance on market governance (usually assisted by strong elements of government intervention). Since then, policy-making by individual large corporations often seems to be replacing associational governance as well as government policy-making in fields of employment categories and rights, pay determination, and the determination of pensions. However, the public goods issues raised by uncertainty and environmental damage bring again into question the adequacy of governance by the market and individual firms. This suggests the need to search for new modes of governance, or new combinations of old ones.

It is therefore time for the research and policy-making agenda to move beyond a focus on flexicurity alone and to examine sustainable security more generally. Labour flexibility is not the only issue at stake in economic innovation; there is not necessarily a trade-off between flexibility and security; explicit labour and social policy is not the only field in which sustainable security can be pursued. The central research task is therefore to interrogate various regimes of policy and practice in order to discover what means are used within them to provide various forms of protection for various kinds of person, and second to consider their likely sustainability.

\section{Executive summary}

The financial crisis helped explain the paradox that workers in countries following the so-called Anglo-American economic model seemed to show more consumer confidence despite the apparent insecurity of employment in less regulated labour markets than those in several continental European countries. People in the former group were less dependent on labour income, as they had extensive access to housing and consumer credit, further supported by secondary financial markets. Ostensibly reliably buoyant housing markets underpinned consumption.

Whether this model was sustainable or not, it draws our attention to the potential separation of consumption capacity from labour-market position. This in turn indicates a need to 
expand the analysis of the relationship between flexibility and security in labour markets beyond the normal scope of labour and social policy to include many other aspects of not only public policy but also corporate practice that affect that relationship.

The discussion goes on to define key terms to be used in the discussion. First, uncertainty and security are the two dependent variables being balanced in any combination of policies and practices. For these purposes, individuals are seen as based within a number of collectivities within which life chances are collectively determined (or CLCs). These collectivities are subject to various forms of governance, which are analyzed in terms of law, government, market, corporate hierarchy, associations, networks and communities. Finally, attention is given to the dimension of sustainability, the capacity of any combinations of policies and practices to endure with self-destructive tendencies.

The governance mechanisms of CLCs are then seen as using (whether sustainably or not) one or more strategies for achieving a certain balance between uncertainty and security: externalization of risk on to other CLCs; postponement of risk-bearing to future periods of time; externalization of risk on to certain members of the CLC itself; widespread sharing within the CLC.

This preparation enables us to analyze any item of policy or practice in terms of the following scheme:

I The main forms of governance involved.

II Relationship to the where, when and among whom questions (issues of place, time and internal distribution).

III Form of externalization, internalization or internal externalization involved; this addresses the degree of inequality produced by the policy or practice.

IV Sustainability probabilities associated with them.

This approach is then used to consider the main policies and practices relevant to the field:

- employment law,

- social policies directly delivering services,

- advancement of skill and employability levels available within the population,

- public promotion and/or protection of sectors and production locations perceived to be of strategic importance, including public employment,

- government demand management,

- insurance and pensions,

- trading relationships among nation states with different export and import patterns,

- consumer credit to sustain mass consumption,

- locally clustered economic sectors,

- the shadow economy,

- managerial organization of activities offering varying degrees of security among different countries and regions, including supply chain management,

- internal labour markets and organization of work and work roles,

- collective bargaining,

- inter-generational transfers and support,

- the protection of property-owning elites from labourmarket uncertainty.

The present paper sets out the terms for a research programme based on these criteria, though it does not itself present the results of research. A first stage in such a programme is to analyze which groups of policies and practices relevant to sustainable security, and with which relative importance, are found within individual national cases, and how these have changed over time within them. This would make possible cross-country comparison. Second, change over time can be studied within national cases, as some types and combinations of types might be fading in significance while others are becoming more prominent in any given country, or more generally. Third, once we have discovered whether different types tend to be found together, or tend to "repel" each other, we may be able to construct theories to account for such associations, which might also assist in relating any observed differences to different balances of class and other interests in the development of policies and practices. It will also be possible to determine how the various types vary in their impact when they appear in different combinations.

\section{Kurzfassung}

Die Wirtschaftskrise hat geholfen, das Paradoxon zu erklären, dass Arbeiter in Ländern, die sich dem sogenannten angloamerikanischen Wirtschaftsmodell verschrieben haben, anscheinend mehr Verbrauchervertrauen zeigen, und das trotz der offensichtlichen Beschäftigungsunsicherheit in Arbeitsmärkten, die weniger reguliert sind als die in den meisten kontinentaleuropäischen Ländern. Menschen ersterer Gruppe waren von ihrem Einkommen weniger abhängig, da sie umfassenden Zugang zu Immobilien- und Konsumentenkrediten hatten und auch von sekundären Finanzmärkten unterstützt wurden. Anscheinend zuverlässig lebhafte Immobilienmärkte unterstützten den Konsum.

$\mathrm{Ob}$ dieses Modell nachhaltig war oder nicht sei dahingestellt; es weist jedenfalls auf die mögliche Trennung von Konsumkapazität und Arbeitsmarktposition hin. Dies zeigt wiederum die Notwendigkeit, die Analyse des Verhältnisses von Flexibilität und Sicherheit in Arbeitsmärkten über den normalen Umfang von Arbeits- und Sozialpolitik hinaus zu erweitern, um viele weitere Aspekte - nicht nur der öffentlichen Ordnung, sondern auch der Geschäftspraktiken - die dieses Verhältnis beeinflussen, mit einzubeziehen. 
Anschließend werden die für die Diskussion relevanten Schlüsselbegriffe definiert. Erstens sind die Unsicherheit und die Sicherheit die zwei abhängigen Variablen, die in jeder Kombination von Politiken und Praktiken abgewogen werden. In dieser Hinsicht werden Individuen als in einer Anzahl von Kollektiven lebend dargestellt, in welchen ihre Chancen im Leben kollektiv bestimmt werden (,Collectivities of Life Chances“ [CLCs]). Diese Kollektive unterliegen verschiedenen Formen der Governance, die mit Bezug auf Gesetz, Regierung, Markt, Geschäftshierarchie, Verbände, Netzwerke und Gemeinschaften analysiert werden. Letztlich wird die Dimension der Nachhaltigkeit, sprich die Fähigkeit, in irgendeiner Kombination von Politiken und Praktiken trotz ihrer selbstzerstörerischen Tendenzen zu überleben, untersucht.

Die Governance-Mechanismen von CLCs werden dann dargestellt, als nutzten sie (ob nachhaltig oder nicht) eine oder mehrere Strategien, um ein gewisses Gleichgewicht zwischen Unsicherheit und Sicherheit zu erlangen: Risiken auf andere CLCs zu externalisieren, das Eingehen von Risiko auf einen späteren Zeitpunkt zu verschieben, Risiken auf bestimmte Mitglieder des eigenen Kollektivs zu verteilen und das weitverbreitete Verteilen von Risiken innerhalb des CLC.

Diese Vorarbeit ermöglicht es uns, jede beliebige Politik oder Praktik gemäß dem folgenden Schema zu analysieren:

1. Die auftretenden Hauptformen der Governance.

2. Die Beziehung zu den „Wo“-, „Wann“- und „Unterwem"-Fragen (Fragen des Ortes, der Zeit und der internen Verteilung).

3. Die auftretenden Formen der Externalisierung, der Internalisierung und der ,internen Externalisierung“; hier wird der von der Politik oder Praktik verursachte Ungleichheitsgrad untersucht.

4. Die damit einhergehenden Nachhaltigkeitsaussichten.

Dieser Ansatz wird dann benutzt, um die für das Gebiet relevanten Hauptpolitiken und -praktiken zu untersuchen:

- das Arbeitsrecht,

- Sozialpolitiken, die Leistungen direkt erbringen,

- das Vorankommen von in der Bevölkerung vorhandenen Kompetenzen und der Beschäftigungsfähigkeit,

- die öffentliche Vermarktung bzw. der Schutz von Sektoren und Produktionsstandorten, die als von strategischem Wert gelten, einschließlich des öffentlichen Dienstes,

- Nachfragemanagement durch die Regierung,

- Versicherung und Rente,

- Handelsbeziehungen zwischen Nationalstaaten, die unterschiedliche Export- und Importmuster aufweisen,

- Konsumentenkredit, um den Massenkonsum aufrecht zu erhalten,

- örtlich gebündelte Wirtschaftssektoren,
- der Schwarzmarkt,

- die betriebswirtschaftliche Organisation von Aktivitäten, die unterschiedliche Sicherheitsgrade zwischen verschiedenen Ländern und Regionen bieten, einschließlich des Supply-Chain-Managements,

- interne Arbeitsmärkte und die Organisation von Arbeit und Arbeitsrollen,

- Tarifverhandlungen,

- intergenerativer Wissenstransfer und intergenerative Unterstützung und

- das Absichern von vermögensbesitzenden Eliten gegen arbeitsmarktbedingte Unsicherheiten.

Der vorliegende Beitrag legt den Rahmen für ein auf diesen Kriterien basierendes Forschungsprogramm fest, obwohl er selbst keine Forschungsergebnisse vorlegt. In einem solchen Programm besteht der erste Schritt darin, zu analysieren, welche Politiken und Praktiken, die für die nachhaltige Sicherheit relevant sind, in einzelnen nationalen Fällen zu finden sind, was ihre jeweilige Wichtigkeit ist und wie sich diese Aspekte in besagten Fällen mit der Zeit verändert haben. Diese Vorgehensweise würde einen internationalen Vergleich ermöglichen. Zweitens kann die Veränderung mit der Zeit in nationalen Fällen näher betrachtet werden, da manche Typen und Typenkombinationen in einem bestimmten Land weniger wichtig werden, während andere an Wichtigkeit gewinnen. Drittens, nachdem wir festgestellt haben, ob verschiedene Typen tendenziell gemeinsam auftreten oder aber sich tendenziell gegenseitig „abstoßen“, könnte es uns gelingen, Theorien aufzustellen, die diese Verhältnisse erklären, was wiederum auch helfen könnte, in der Entwicklung von Politiken und Praktiken beobachtete Unterschiede mit verschiedenen Gewichtungen von Klassen- und anderen Interessen in Beziehung zu bringen. Es wird auch möglich sein, festzustellen, wie sich die verschiedenen Typen in ihren Auswirkungen unterscheiden, wenn sie in unterschiedlichen Kombinationen auftreten.

Acknowledgements This paper has been prepared as part of my work for European Union Framework Programme 7 project "The Governance of Uncertainty and Sustainability: Tensions and Opportunities" (GUSTO) (grant no. 225301). I am very grateful to my colleagues within this programme for many of the ideas contained within it.

\section{References}

Beck, U.: Risikogesellschaft. Suhrkamp, Frankfurt a. M. (1986)

Bellofiore, R., Halevi, J.: Deconstructing Labor. A Marxian-Kaleckian perspective on what is new in contemporary capitalism and economics. In: Gnos, C., Rochon, L.-P. (eds.) Employment, Growth and Development. A Post-Keynesian Approach. Elgar, Cheltenham (2009)

Berger, S., Piore, M.: Dualism and Discontinuity in Industrial Societies. Cambridge University Press, Cambridge (1979) 
Blanchard, O.J., Summers, L.H.: Hysteresis and the European Unemployment Problem. NBER Macroeconomic Annual (1986)

Burroni, L.: Italy's Changing Regional Economy. In: Glassmann, U., Koppl, S., Rorig, K. (eds.) Country report Italy. Bundeszentrale für Politische Bildung, Bonn (2009)

Coase, R.: The nature of the firm. Economica 4 386-405 (1937)

Crouch, C.: Industrial Relations and European State Traditions. Oxford University Press, Oxford (1993)

Crouch, C.: Capitalist Diversity and Change. Oxford University Press, Oxford (2006)

Crouch, C.: Privatised Keynesianism: an unacknowledged policy regime. Br. J. Politics Int. Relat. 11, 382-399 (2009)

Davies, P., Freedland, M.: Towards a Flexible Labour Market: Labour Legislation and Regulation since the 1990s. Oxford University Press, Oxford (2007)

Erne, R.: European Unions: Labor's Quest for a Transnational Democracy. Cornell University Press, Ithaca, NY (2008)

Esping-Andersen, G.: The Three Worlds of Welfare Capitalism. Polity Press, Cambridge (1990)

Esping-Andersen, G.: The Social Foundations of Post-Industrial Economies. Oxford University Press, Oxford (1999)

European Commission: Growth, Competitiveness and Employment. Office for Official Publication of the European Communities, Luxembourg (1993)

European Commission: A Sustainable Development Strategy. Office for Official Publication of the European Communities, Luxembourg (2001)

European Commission: Working Together for Growth and Jobs. Integrated Guidelines for Growth and Jobs (2005-2008). Office for Official Publication of the European Communities, Luxembourg (2005)

European Commission: Green Book. Office for Official Publication of the European Communities, Luxembourg (2006)

European Commission: An Energy Policy for Europe. Office for Official Publication of the European Communities, Luxembourg (2007)

Eurostat: Employment in Europe 2007. Office for Official Publication of the European Communities, Luxembourg (2007)

Eurostat: Europe in Figures 2009. Office for Official Publication of the European Communities, Luxembourg (2009)

Fama, E.F.: Risk, return and equilibrium. J. Polit. Econ. 79(1), 30-55 (1971)

Fama, E.F.: Efficient capital markets II. J. Finance XVVI(5), 1575-1617 (1991)

Ferrera, M.: The "Southern Model" of social Europe. J. Eur. Soc. Policy 6(1), 17-37 (1996)

Hayward, J. (ed.): Industrial Enterprise and European Integration: From National to International Champions. Oxford University Press, Oxford (1995)

Hay, C., Riiheläinen, J.M., Smith, N.J., Watson, M.: Ireland: the outside inside. In: Dyson, K. (ed.) The Euro at 10. Oxford University Press, Oxford (2008)

Hollingsworth, J.R., Boyer, R. (eds.): Contemporary Capitalism: The Embeddedness of Institutions. Cambridge University Press, Cambridge (1997)

Hollingsworth, J.R., Müller, K.H., Hollingsworth, E.J.: Advancing Socio-Economics: An Institutionalist Perspective. Rowman and Littlefield, Lanham (2002)

Jurado Guerrero, T.: Why Do Spanish Young People Stay Longer at Home than the French? The Role of Employment, Housing and Social Policies. European University Institute: unpublished $\mathrm{PhD}$ thesis, Florence (1999)

Kenney, M.: Understanding Silicon Valley: The Anatomy of an Entrepreneurial Region. Stanford University Press, Stanford (2000)
Knegt, R. (ed.): The Employment Contract as an Exclusionary Device. An Analysis on the Basis of 25 Years of Developments in The Netherlands. Intersentia, Antwerp (2008)

Knight, F.H.: Risk, Uncertainty and Profit. Houghton Mifflin, Boston (1921)

Kristensen, P.H., Karnøe, P., Andersen, P.H. (eds): Mobilizing Resources and Generating Competencies. The remarkable success of small and medium sized enterprises in the Danish Business system. Copenhagen Business School Press, Copenhagen (1999)

Loveridge, R., Mok, A.L.: Theories of Labour Market Segmentation: A Critique. Nijhoff, The Hague (1979)

Luhmann, N.: Soziologie des Risikos. De Gruyter, Berlin (1991)

Majone, G.: Deregulation or Re-regulation? Regulatory Reform in Europe and the United States. Pinter, London (1990)

Muffels, R., Chung, H., Fouarge, D., Klammer, U., Luijkx, R., Manzoni, A., Thiel, A., Wilthagen, T.: Flexibility and Security over the Life Course. European Foundation for the Improvement of Working and Living Conditions, Dublin (2008)

Naldini, M.: Evolution of Social Policy and the Institutional Definition of Family Models: The Italian and Spanish Cases in Historical and Comparative Perspective. European University Institute: unpublished $\mathrm{PhD}$ thesis, Florence (1999)

Olson, M.: The Theory of Collective Action. Harvard University Press, Cambridge, Mass (1966)

Olson, M.: The Rise and Decline of Nations. Yale University Press, New Haven (1982)

OECD: The Jobs Study. OECD, Paris (1994)

OECD: Boosting Jobs and Incomes. Policy Lessons from Reassessing the OECD Jobs Study. OECD, Paris (2006a)

OECD: Competitive Cities in the Global Economy. OECD, Paris (2006b)

Pyke, F., Beccatini, G., Sengenberger, W.: Industrial Districts and InterFirm Co-operation in Italy. International Institute for Labour Studies, Geneva (1990)

Rhodes, M.: The Political Economy of Social Pacts: "Competitive Corporatism" and European Welfare Reform. In: Pierson, P. (ed.) The New Politics of the Welfare State. Oxford University Press, Oxford (2001)

Rogowski (ed.): The European Social Model and Transitional Labour Markets: Law and Policy. Ashgate, Aldershot (2008)

Rueda, D.: Insider-outsider politics in industrialized democracies: the challenge to social democratic parties. Am. Political Sci. Rev. 99(1), 61-74 (2005)

Rueda, D.: Social Democracy Inside Out: Partisanship and Labour Market Policy (2007)

Schmitter, P.C., Streeck, W. (eds.): Private Interest Government: Beyond Market and State. Sage, London (1985)

Schneider, F.: Shadow economies and corruption all over the world. Economics 1(9) (2007)

Standing, G.: Global Labour Flexibility. Macmillan, London (1999)

Stinchcombe, A.L.: Social structure and organizations. In: March, J.G. (ed.) Handbook of Organization, pp. 142-193. Rand McNally, Chicago, IL (1965)

Talani, Cerviño, E.: Mediterranean labour and the impact of economic and monetary union: mass unemployment or labour market flexibility? In: Overbeek, H. (ed.) The Political Economy of European Employment. Routledge, London (2003)

Traxler, F.: Bargaining, (de)centralization, macroeconomic performance and control over the employment relationship. Br. J. Ind. Rel. 41, 1-27 (2003)

Traxler, F., Blaschke, S., Kittel, B.: National Labour Relations in Internationalized Markets. Oxford University Press, Oxford (2001)

Traxler, F., Brandl, B., Glassner, V.: Pattern bargaining: an investigation into its agency, context and evidence. Br. J. Ind. Rel. 46(1), 33-58 (2008) 
Wallerstein, I.: The Modern World System. Academic Press, New York (1974)

Williamson, O.E.: Markets and Hierarchies: Analysis and Antitrust Implications: A Study in the Economics of Internal Organization. Free Press, New York (1975)

Williamson, O.E.: The Economic Institutions of Capitalism. Free Press, New York (1985)

Wilthagen, T.: Managing social risks with transitional labour markets. In: Mosley, H., O'Reilly, J., Schömann, K. (eds.) Labour Markets, Gender and Institutional Change: Essays in Honour of Günther Schmid, pp. 264-289. Edward Elgar, Cheltenham (2002)

Wilthagen, T, Tros, F.: The Concept of 'Flexicurity: a new approach to regulating employment and labour markets' in 'Flexicurity: Con- ceptual Issues and Political Implementation in Europe'. Transfer, 10, 2 (2004)

Colin Crouch is Professor of Governance and Public Management at the Business School of Warwick University. He is also the External Scientific member of the Max-Planck-Institute for the Study of Societies at Cologne. He is currently studying changes in the governance of labour markets and social policy in eastern and western Europe. His most recent books include: Social Change in Western Europe (1999); Postdemocrazia (2003) [in English as Post-Democracy (2004)]; and Capitalist Diversity and Change: Recombinant Governance and Institutional Entrepreneurs (2005).

e-mail: c.crouch@warwick.ac.uk 